\title{
Diffuse pseudotumoral cerebral Schistosomiasis mansoni: a new form of presentation
}

\author{
Thiago Cardoso Vale', Marcelo Magaldi Oliveira², Silvio Roberto de Sousa- \\ Pereira', José Roberto Lambertucci³, Sebastião Nataniel Silva Gusmão²
}

\begin{abstract}
We describe two cases of cerebral schistosomiasis mansoni with multiple pseudotumoral lesions diagnosed by stereotactic brain biopsy. Both patients presented with seizures and one with left visual impairment. Imaging techniques revealed multiple brain lesions involving cerebral parenchyma, pons, cerebellum and thalamus. Brain histopathologic specimens of the patients showed multiple schistosomal granulomas in distinct evolutive phases. All patients presented good clinical response to treatment and reversion of the brain lesions. This new form of neuroschistosomiasis must be considered by those who work in the endemic area for Schistosoma mansoni.
\end{abstract}

\section{KEY-WORDS}

Schistosoma mansoni, neuroschistosomiasis, schistosomiasis, cerebrum/injuries.

\section{RESUMO}

Forma pseudotumoral difusa da esquistossomose cerebral: uma nova forma de apresentação São descritos dois casos de esquistossomose mansônica cerebral com lesões pseudotumorais múltiplas diagnosticadas por biópsia estereotáxica. Ambos os pacientes apresentaram-se com crises epilépticas e um deles com distúrbio visual. Estudos de neuroimagem revelaram múltiplas lesões cerebrais envolvendo parênquima cerebral, ponte, cerebelo e tálamo. Espécimes histopatológicos cerebrais dos pacientes demonstraram múltiplos granulomas esquistossomóticos em distintas fases evolutivas. Ambos os pacientes apresentaram boa resposta clínica ao tratamento e reversão das lesões cerebrais. Essa nova forma de neuroesquistossomose deve ser considerada por aqueles que trabalham em área endêmica para Schistosoma mansoni.

\section{PALAVRAS-CHAVE}

Schistosoma mansoni, neuroesquistossomose, esquistossomose, cérebro/lesões.

\section{Introduction}

Schistosomiasis is a parasitic infection caused by the digenetic trematode of the Schistosoma genre. This parasite uses the man and other mammals as definitive hosts and aquatic clams as intermediate hosts. There are five species of Schistosoma capable of causing disease in humans: S. mansoni, S. japonicum, S. haematobium, S. intercalatum and $S$. mekongii. ${ }^{11}$ Schistosomiasis affects about 200 million individuals in Brazil, Suriname, Venezuela, several of the Caribbean Islands, Egypt, many countries of the equatorial west and the center-south of Africa and Arabic Peninsula. ${ }^{5}$ Yet, due to the present easiness of locomotion and migration, $S$. mansoni infection has been more frequently found in non-endemic countries. ${ }^{4,9}$ It is one of the most important endemic infectious diseases in Brazil, with an estimated prevalence rate of $5 \%{ }^{6}$

Involvement of the central nervous system (CNS) by $S$. mansoni is the most common ectopic form of the disease being the spinal cord the most frequently affected organ. ${ }^{8,11}$ S. japonicum is the major causative agent of cerebral schistosomiasis (CS). ${ }^{11}$ The tumoral and pseudotumoral forms of the CS have already been reported. However, to our knowledge, a diffuse pseudotumoral form due to $S$. mansoni infection has not been described yet. The aim of this work is to report two cases of diffusely located CS due to $S$. mansoni infection and to suggest a new presentation of CNS involvement in schistosomiasis.

1. Neurology Division, University Hospital of the Federal University of Minas Gerais (UFMG), Belo Horizonte, MG, Brazil.

2. Neurosurgery Division, Faculty of Medicine of the UFMG, Belo Horizonte, MG, Brazil.

3. Infectious Diseases Division, Faculty of Medicine of the UFMG, Belo Horizonte, MG, Brazil. 


\section{Case report 1}

A previously healthy 18 -year-old female was admitted to hospital after seizures of recent onset. Neurological examination revealed vertical nistagmus and right hyperreflexia. There were no motor and cognitive symptoms. Cranial computed tomography (CT) showed hyperdense gadolinium-enhancing lesions in the left temporal lobe, thalamus and pons. Stereotactic biopsy of the temporal lobe lesion showed multiple schistosomal granulomas in different evolutionary stages. Parasitological stool examination found ova of S. mansoni (Figure 1). The patient was treated with praziquantel associated with phenytoin and improved quickly. CT scan, performed three months later, showed total recovery of the brain lesion (Figure 2). In follow-up consultations, the patient was seizure-free and phenytoin was stopped.

\section{Case report 2}

A 29-year-old woman was admitted to hospital due to episodes of tonic-clonic seizures and left visual impairment. Neurological examination was unrevealing, except for left field homonymous hemianopsia. Fundus exam was normal. Cranial CT scans showed a hypodense lesion in the right parieto-occipital area and diffuse calcifications secondary to neurocysticercosis, a diagnosis established in her childhood (Figure 3). Brain MRI revealedthe nodular aspect of the parieto-occipital lesion. MRI also showed the a similar lesion in

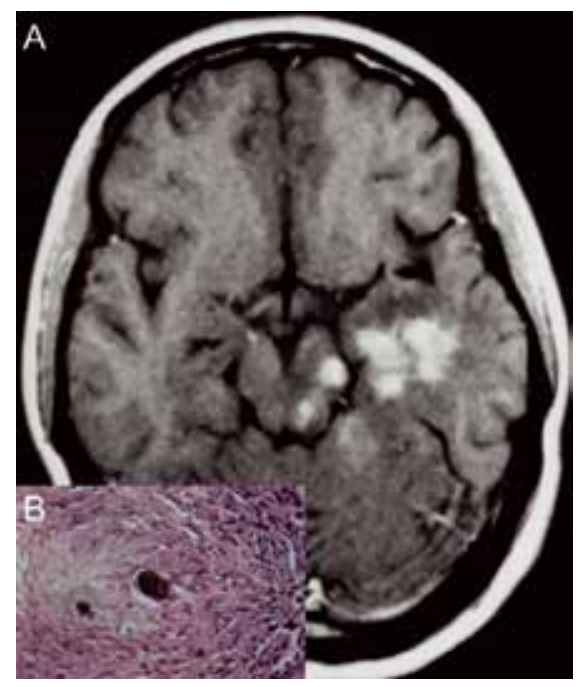

Figure 1 - Cranial computed tomography showing left-sided lesions in the thalamus, pons and temporal lobe. In the bottom left box, Schistosoma mansoni eggs in brain biopsy (HE 200x). the left cerebellum extending to the vermis and middle cerebellar peduncle. Multiple granulomas with necrotic centers around which $S$. mansoni ova were found in the brain biopsy; egg walls were acid-fast stained with typical lateral spines. The final pathologic diagnosis was granulomatous encephalitis caused by $S$. mansoni eggs (Figure 4). Praziquantel ( $60 \mathrm{mg} / \mathrm{kg}$, body weight, single dose) and prednisone ( $1 \mathrm{mg} / \mathrm{kg}$, body weight, daily for 6 months) were administered and the patient improved rapidly. Ten months later, MRI showed a faint hyperintense signal in the affected area (Figure 5). Patient persisted with the left field homonymous hemianopsia in a follow-up consultation.

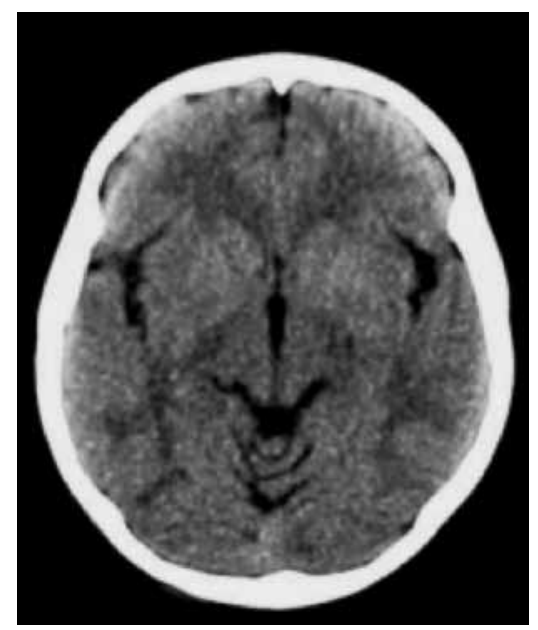

Figure 2 - Cranial computed tomography performed three months later showing complete resolution of lesions.

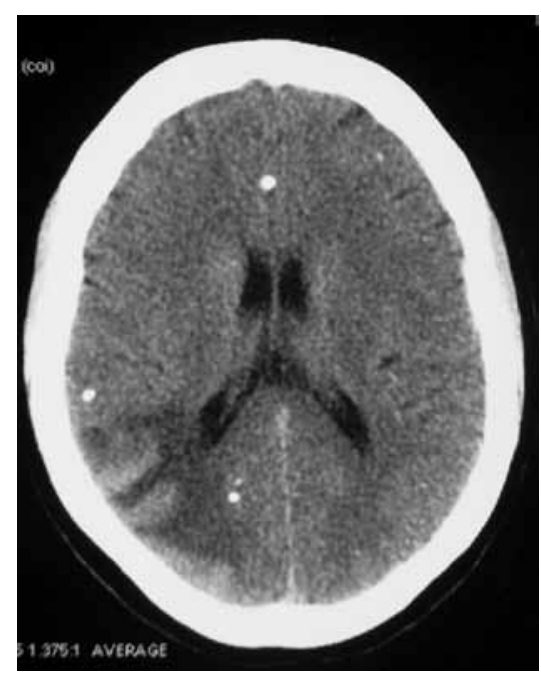

Figure 3 - Enhanced cranial computed tomography scan with a hypodense lesion in the right parietooccipital lobe and residual diffuse calcifications. 


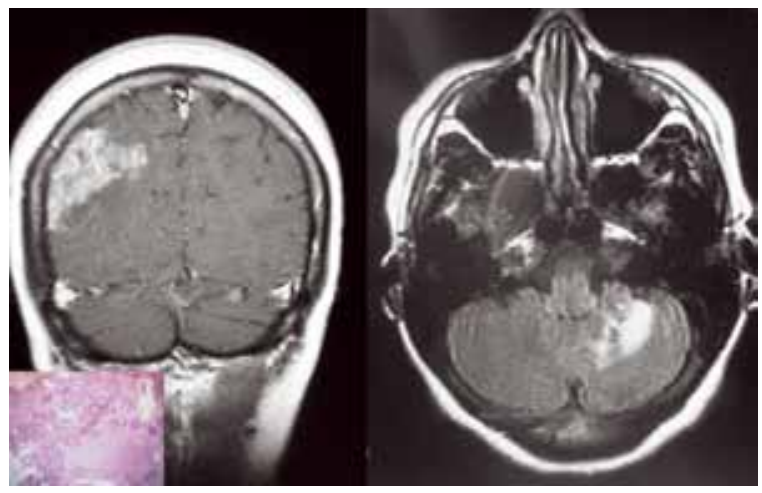

Figure 4 - In the left corner, a T1-weighted gadolinium-enhanced brain magnetic resonance imaging showing a right parietooccipital lesion. In the right corner, a T2-weighted brain magnetic resonance imaging showing a left middle cerebellar peduncle lesion. In the bottom left box, multiple Schistosoma mansoni eggs in brain biopsy (HE 100x).

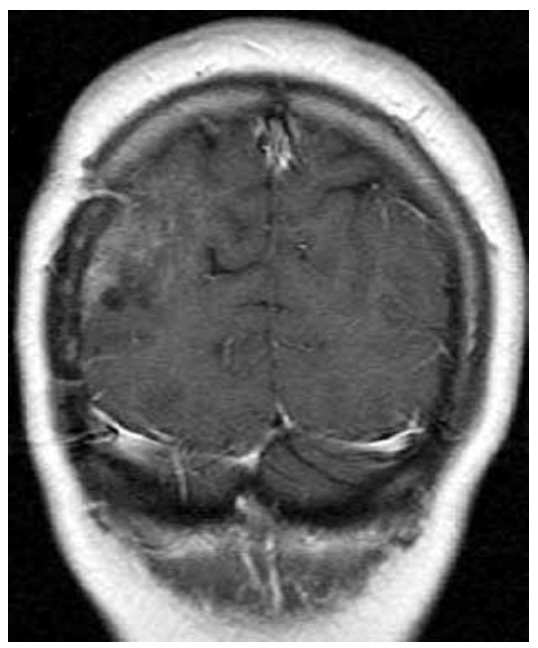

Figure 5 - T1-weighted gadolinium-enhanced brain magnetic resonance imaging performed ten months later showing a faint hyperintense signal in the right parieto-occipital area.

\section{Discussion}

Cerebral schistosomiasis is a rare condition characterized by anomalous deposition of $S$. mansoni eggs in the CNS. Worms and eggs reach the brain by the arterial system or through retrograde blood venous flow (Batson's vertebral plexus). S. mansoni eggs and worms in the brain elicit a protean immunological response and causes vascular damage. Granulomas formation, in different evolutionary stages, are the usual pathological finding. It is speculated that vasculitis caused by immune complexes is also involved in the pathogenesis of brain lesion in some patients. ${ }^{1,7,8,10,11}$
Cerebral schistosomiasis may provoke a clinical picture of intracranial hypertension associated with brain and/or cerebellar granulomatous lesions. A slow-expanding cerebral lesion, surrounded by edema and mass effect may mimic a brain tumour and should be called pseudotumoral lesion. ${ }^{1,4}$ Isolated brain pseudotumors have been previously reported in schistosomiasis mansoni, but the presentation with multiple brain lesions makes our cases unique. A diffuse massive pseudotumoral brain involvement has been reported once in S. mekongii infection. ${ }^{3}$ Randomly migration of worms to brain vessels and deposition of circulating immune complexes are the most likely explanation for the development of diffuse brain involvement.

Headache, seizures, focal motor deficits, ataxia, nystagmus, nausea and vomiting are the usual clinical manifestations of brain involvement. They are caused by increased intracranial pressure and focal cerebrallesions. ${ }^{2,10}$ The tumor-like form of cerebellar schistosomiasis is a life-threatening condition. ${ }^{10}$

Stereotactic brain biopsy was used to diagnose the disease. Both patients were treated with schistosomicides and one also received steroids followed by clinical revovery. Complete resolution of brain lesions was documented by CT in one patient; the other case had a residual alteration on MRI ten months later. Physicians all over the world and particularly those who work in the endemic areas for S. mansoni should be aware of this presentation of schistosomiasis.

\section{References}

1. Andrade Filho AS, Queiroz AC, Freire AC, Lima LC, Filho CA, Amado IN, et al. Pseudotumoral form of neuroschistosomiasis: report of three cases. Braz J Infect Dis. 2007;11(4):435-8.

2. Braga BP, Da Costa Junior LB, Lambertucci JR. Magnetic resonance imaging of cerebellar schistosomiasis mansoni. Rev Soc Bras Med Trop. 2003;36(5):635-6.

3. Carod-Artal FJ. Neurological complications of Schistosoma infection. Trans R Soc Trop Med Hyg. 2008;102(2):107-16.

4. Carod-Artal FJ. Neuroschistosomiasis. Expert Rev Anti Infect Ther. 2010;8(11):1307-18.

5. Gryseels B, Polman K, Clerinx J, Kestens L. Human schistosomiasis. Lancet. 2006;368(9541):1106-18.

6. Lambertucci JR, Gerspacher-Lara R, Pinto-Silva RA, Barbosa MM, Teixeira R, Barbosa HF, et al. [The Queixadinha Project: morbidity and control of schistosomiasis in an endemic area in the northeast of Minas Gerais, Brazil]. Rev Soc Bras Med Trop. 1996;29(2):127-35.

7. Lambertucci JR, Serufo JC, Gerspacher-Lara R, Rayes AA, Teixeira R, Nobre V, et al. Schistosoma mansoni: assessment of morbidity before and after control. Acta Trop. 2000;77(1):101-9.

8. Lambertucci JR, Silva LC, Do Amaral RS. Guidelines for the diagnosis and treatment of schistosomal myeloradiculopathy. Rev Soc Bras Med Trop. 2007;40(5):574-81. 
9. Lambertucci JR. Schistosoma mansoni: pathological and clinical aspects. In: Jordan P, editor. Human schistosomiasis. Wallingford: Cab International; 1993. p. 195-235.

10. Pittella JE, Gusmão SN, Carvalho GT, Da Silveira RL, Campos GF. Tumoral form of cerebral schistosomiasis mansoni. A report of four cases and a review of the literature. Clin Neurol Neurosurg. 1996;98(1):15-20.

11. Pittella JE, Lana-Peixoto MA. Brain involvement in hepatosplenic Schistosomiasis mansoni. Brain. 1981;104(3):621-32.
12. Pittella JE. Neuroschistosomiasis. Brain Pathol. 1997;7(1):649-62.

Endereço para correspondência

Sebastião Nataniel Silva Gusmão

Faculdade de Medicina - Universidade Federal de Minas Gerais

Av. Alfredo Balena, 190

30130-100 - Belo Horizonte, MG, Brazil

E-mail: sebastiaogusmao@gmail.com 